\title{
Understanding Consumer Travel Behavior during COVID-19
}

\author{
Xianglan Chen ${ }^{1}$, Yachao Duan ${ }^{2}$, Laiba Ali ${ }^{3}$, Yahui Duan ${ }^{4}$ and Kisang Ryu ${ }^{5, *}$ (i) \\ 1 Center for the Cognitive Science of Language, Beijing Language and Culture University, \\ Beijing 100083, China; cx1617@126.com \\ 2 Sinounited Investment Group Corporation, Beijing 100086, China; yachao0922@sina.com \\ 3 Faculty of Tourism, Eastern Mediterranean University, Famagusta 99628, Turkey; laiba.ali@emu.edu.tr \\ 4 School of Foreign Language and Application, The Australian National University, \\ Canberra, ACT 2601, Australia; duanyahui92@163.com \\ 5 The College of Hospitality and Tourism Management, Sejong University, Seoul 143-747, Korea \\ * Correspondence: kryu11@sejong.ac.kr
}

check for updates

Citation: Chen, X.; Duan, Y.; Ali, L.; Duan, Y.; Ryu, K. Understanding Consumer Travel Behavior during COVID-19. Sustainability 2021, 13, 13330. https://doi.org/10.3390/ su132313330

Academic Editors: J. Andres CocaStefaniak and Manfred Max Bergman

Received: 5 September 2021

Accepted: 23 November 2021

Published: 1 December 2021

Publisher's Note: MDPI stays neutral with regard to jurisdictional claims in published maps and institutional affiliations.

Copyright: (c) 2021 by the authors. Licensee MDPI, Basel, Switzerland. This article is an open access article distributed under the terms and conditions of the Creative Commons Attribution (CC BY) license (https:/ / creativecommons.org/licenses/by/ $4.0 /)$.

\begin{abstract}
Since the COVID-19 outbreak worldwide, the global tourism industry has taken a severe hit. To fully understand the impact of the pandemic on tourists' travel behavior, an intercultural survey was carried out through a large-scale online questionnaire. This survey aims to determine whether cultural differences and different ages might play a role in tourists' behavior during the COVID19. Data collected from 942 respondents from mainland China and overseas through different age groups were subjected to data analysis. The results demonstrate cognition and consumer behavior differentiate culturally and significantly between different ages, which is highlighted when they choose travel modes, transportation, and companions. The implications of the study are also provided in the end.
\end{abstract}

Keywords: consumer behavior; travel behavior; COVID-19

\section{Introduction}

The novel coronavirus pandemic (COVID-19) has adversely affected domestic and international tourism [1]. In 2020, international tourist arrivals declined by $74 \%$, resulting in the loss of USD 1.3 trillion in export revenues [2,3]. Governments across the globe have put in place a range of measures, i.e., lockdowns, wearing face masks, and travel restrictions, as tactics for tourism and trade to restrict the spread of infectious diseases [4]. Many countries have implemented severe restrictions and strict border controls on domestic and international traveling $[1,5]$. For instance, the United States, at a national level, imposed extensive travel restrictions on the Schengen countries [6].

In contrast, the European Union (E.U.) also closed its borders for all the countries other than E.U. nationals [7]. Therefore, controlling COVID-19 and tourism recovery highly depends on how people respond to such restrictions. However, these restrictions have become unbearable for the public in many countries [8]. From the USA to Brazil, the European Union to Africa, and Russia to China, most people's lives are heavily regulated by the policies of governments around the world. These policies led to mixed reviews at the personal and medical levels, which resulted in different compliance rates and adoption of the restrictions. An international survey by [9] from the samples of 23 countries showed that people from individualistic societies (e.g., Australia, United Kingdom, United States, etc.) were much more against their countries' restrictive measures to control the spread of COVID-19 pandemic, as compared to people from collectivist societies (e.g., China, India, Vietnam., etc.) who, despite some differences, were, in general, more in favor of the preventive measures of their nations. In line with the survey results, it can be seen that the people's responses to the COVID-19 Pandemic's preventive measures are possibly due to different cultural perceptions and cognitions of people. Therefore, it is argued that the closure of the tourism and hospitality industry has resulted in negative social and 
cultural differences [10]. Based on this argument, the need for a strategy for recovery is heightened [11]. However, the impact of COVID-19 on risk perceptions, cognitions, cultural differences, behaviors, and related outcomes on local and international tourists has been highly overlooked. Therefore, it is essential to understand the impact of culture and cognition on consumer behavior during COVID-19.

Although previous studies have discussed the interrelationships between travel, risk, and disasters [12-19], these studies have not specifically addressed the type of changes that occurred due to COVID-19, which is beyond anything experienced previously at such a global scale. Furthermore, although many scholars' focus on the tourism industry is undoubtedly on the implications of COVID-19 travel restrictions, few studies have focused on the changing behaviors of tourists due to COVID-19 as a result of cultural differences.

Therefore, the present study addresses these gaps in the tourism literature by focusing on the effect of COVID-19 on tourists' travel behaviors and advocates for the importance of understanding the changes that travelers experience in their cognitive and consumption behaviors due to various cultural differences post COVID-19. Specifically, this study draws on a sample of Chinese respondents to assess the research aim. The remainder of the study is arranged as follows. First, the next section reviews the literature on the tourists risk perceptions, natural disasters, destination image, the impact of COVID-19 on tourist behaviors, the impact of COVID-19 in China, and hypotheses development. It is followed by the research methodology, analysis, results, discussion, and conclusion.

\section{Literature Review}

\subsection{Tourists' Risk Perceptions}

One global issue of interest in tourism is the exploration of how travelers perceive the concept of risk and safety. Based on risk perceptions, Roehl and Fesenmaier [18] classified tourists into three groups: Operational risk, neutral risk, and place risk. Tourists with functional risk groups consider the possibility of organizational, equipment, and mechanical problems as the main foundation of tourism-related risks. Tourists in the neutral risk group do not consider any risk related to tourism or the destination. At the same time, tourists in place risk groups consider visiting hazardous locations. A study by [19] also investigated tourists' risk perception while traveling. Likewise, ref. [20] argued that the risk influences individuals' perceptions of their decision processes, especially when the outcomes of the decisions are uncertain. Risk creates emotions that generate anxiety and fear, bringing unknown consequences and preventing travel decisions [21-23].

\subsection{Natural Disasters}

The second concept related to this study is natural disasters, which are the forces of nature that cause catastrophic events. In general, hurricanes, floods, bushfires, tsunamis, earthquakes, heatwaves, and droughts always occur in some parts of the world, leading to the loss of life and creating economic, physical, and social damage [24-26]. Although natural disasters are unavoidable because they are beyond human control, people have learned to manage the broader riskscape of these events and live with them. However, due to the increasing intricacy of socio-ecological systems, the impacts of disasters have significantly increased and exacerbated the effects of climate change in the highly globalized world [27]. For example, an earthquake in Mexico led to a loss of US $\$ 135$ billion [28]. Likewise, lately, epidemics such as COVID-19 have also served almost all the destinations in the world as a natural disaster. Ref. [29] suggested that the risk perceptions related to international tourism vary depending on tourists' role and preferences for familiarity or novelty with the destination. Moreover, these tourists might be capable of framing such risk as an exciting part of tourism, which proposes a pursuit for novelty. Thus, it can be assumed that familiarity with the destination decreases the risks related to the COVID-19 pandemic. 


\subsection{Impact of Epidemics on Tourists' Risk Perceptions and Behavior}

Tourism studies, as compared to psychological and economic studies, define risk perceptions in many ways, mainly as tourists' anxiety, fear, nervousness, and worry [30,31]. In the transmission of contagious diseases, tourism has previously been described as one of the leading factors [32]. In addition, tourists traveling from remote areas to their home countries may bring foreign pathogens, and international tourism can transmit novel infectious diseases to populations of the world [33]. Some of the health-related risks in tourism are sexually transmitted infections, schistosomiasis, Legionnaires' disease, HIV, SARS, and COVID-19 [34,35]. Even though many studies in the literature have reported the impact of epidemics such as the SARS outbreak on tourists' risk perceptions and behaviors, perceived control, and previous experience [35], their results have described the influence of pandemics on different types of travels without identifying the importance of many missing factors affecting tourists' risk perceptions and behaviors, making it a critical avenue to study.

\subsection{Destination Image}

The third concept of this study is related to the cognitive structure of destination image, which is examined in the literature in many ways. Destination image has received significant attention in tourism research [36,37]. To promote destination image efficiently in the market, it is essential to identify the strengths and weaknesses [36,38]. Previous studies have discussed destination image as a multidimensional concept that includes two components of cognitive and affective destination image [39]. Cognitive destination image describes the beliefs of tourists related to the destination based on their assessments of the attributes of destination [40,41], whereas affective destination image is related to feelings of individuals towards the destination [42,43]. Recently, several studies have proposed the cognitive-affective nature of destination image. It is believed that the image is integrated by affective evaluations of a tourist destination and the individuals' cognitive evaluations $[41,42,44-46]$. These components of destination image collectively show the perceptions and behavioral intentions towards the destination and can be understood as destination building blocks.

\subsection{Impact of COVID-19 on Consumer Behaviors}

COVID-19 has resulted in changes to the lifestyles of consumers [2]. The slogans associated with the virus have become well known to us, such as "washing hands more often", "keep your distance from one-two meters", "and wear masks whenever you go outside". Based on news and internet sources, it is also acknowledged that people in different countries have varying perceptions about the virus. In countries such as China and Korea, there is consensus on the need to stay at home and wear masks when leaving the house to control the spread of COVID-19. However, in other countries such as Italy and the USA, this may not be the case. It has been reported that after the epidemic, there will be notable improvements in legislation related to people's lifestyles, animal ethics, and values. It is argued that people will be more considerate of the relationship between man and nature, with more rational attitudes, demonstrating more respect for nature, and more kindness towards wild animals. The measures taken to combat and control the pandemic have highlighted people's honesty, kindness, integrity, fairness, and capacity for love. According to [42,45], post-COVID-19, there will be a new sublimation in dealing with relationships between people. People will have increased respect for medical staff and soldiers who are not afraid to sacrifice their lives to save others. The importance of a harmonious relationship between people has prompted people's attention to shift from power, wealth, and fame to respect and awe for life [46].

\subsection{The Impact of COVID-19 on Tourism}

The second-to-last concept concerns pandemics such as COVID-19 from the cognitive perspective [47-49]. Recently published research on the impact of COVID-19 focused on 
statistical data, contingency measures, confidence index surveys, views, and comments, and impacts of the crisis on organization systems, including industry and enterprises and crisis management [50-52]. Ref. [53] believed that the impacts of a global pandemic on tourists would incur changes to people's lifestyles and tourism activities. Since the tourism industry during COVID-19 remains highly uncertain, the regency of COVID-19 suggests that there is much to explore about the tourism industry [54].

In the long term, the hospitality and tourism industries are more resistant to shocks than in the short term [4]. Over the years, the industry has suffered from many crises, including natural disasters, wars, emergencies threatening destination securities, pandemics, and epidemics [35]. Compared to other human-induced and natural disasters, the COVID-19 pandemic is different due to its worldwide ravaging and omnipresent impact on economies and people. The novel coronavirus has severely affected the travel and tourism industry as it has spread to every corner of the globe $[4,6]$. Essentially, the affected groups during this period are airlines, hotels, restaurants, casinos, cruises, destinations, and all other internal markets that have faced economic impacts and environmental and social consequences [31]. If the impact of COVID-19 on these groups is understood, it could facilitate the reset and recovery of the tourism sector. However, these groups have different sub-groups whose composition is distinct from the general public, and therefore their behavior, perceptions, and risk perceptions may differ from the residents [12].

\subsection{Impact of COVID-19 in China}

COVID-19 is an infectious disease and is a member of the coronaviridae family and the nidovirales group [55]. The virus can be found in the respiratory, enteric, hepatic, and neurological diseases that are becoming widespread in many mammals, humans, and bird species [55,56]. Furthermore, it is one of the RNA-enveloped viruses [57,58]. The virus transmits from person to person via droplets or direct contact. In China, the COVID-19 spread began at the Chinese Spring Festival in 2020. The initial and most prominently hit zone of China was the Hubei province. However, within a couple of days, the deadly infection spread everywhere among urban communities and towns throughout the country. The government of China responded to the virus immediately and imposed preventive approaches and measures to get through and assist people from infecting the virus $[59,60]$.

Regarding the damage to the tourism industry, the National Bureau of Statistics reported that from January to February in 2020, the total retail sales of consumer goods stood at 5213 billion yuan, a year-on-year decrease of $20.5 \%$, of which catering revenue dropped markedly by $43.1 \%$. In addition, room revenue in the accommodation sector above the designated size fell by approximately 50\%. As a result, the National Service Industry Index of Production decreased by $13.0 \%$ on a year-on-year basis. In addition, the national consumer price rose by $5.3 \%$ year on year. The survey on the unemployment rate in cities and towns in China showed increases of $5.3 \%$ and $6.2 \%$, respectively, up by 0.1 and 0.9 percentage points from the previous month. In addition, the total import and export volume reached 4123.8 billion yuan, a year-on-year decrease of $9.6 \%$.

According to data released by the China Tourism Academy, the number of domestic tourists and the tourism revenue in the first quarter of 2020 was estimated to show negative growth of $56 \%$ and $69 \%$, respectively. The China Tourism Academy's report on the impact of COVID-19 on the tourism economy was simulated based on optimistic, benchmark, and pessimistic calculations. The benchmark result shows that, due to COVID-19, domestic tourists were predicted to decline by 932 million in 2020, an equivalent value of 1.18 trillion yuan. Furthermore, in 2020, inbound tourist trips and international tourism revenue ere predicted to see negative growth of $34.7 \%$ and $40.6 \%$, respectively, equating to a decrease of 50.32 million tourists and 53.4 billion yuan in revenue. The number of tourists visiting friends and relatives also decreased by more than $76 \%$ year-on-year. The radius of the destination activity area continued to shrink to about $2 \mathrm{~km}$, resulting in the reduction of expected consumption by nearly half. According to the preliminary statistics by the Ministry of Transport, during the ten days of the Spring Festival holiday in 2020, the railway, 
roads, and waterways across the country received 190 million passengers, a decrease of nearly $73 \%$ compared with the same period last year [61].

The purpose of this empirical study is to obtain first-hand information from tourists who have experienced the crisis of COVID-19 in their countries, as they have experienced the changing behavior regarding their traveling patterns due to COVID-19 and can explain their sensitivity towards crisis and the implications that can be drawn from COVID19 for the government, industry, and enterprises in terms of market recovery and the establishment of a tourism crisis management system.

\section{Methodology}

\subsection{Measurement Scales}

This study has applied the following criteria to finalize the questionnaire items. First, after the COVID-19 outbreak, feedback on the questionnaire items was gathered from scholars, industry experts, and college and post-graduate students. The questions were related to the general concerns of COVID-19 impacts on tourism and the changes travelers experience in their behaviors regarding traveling. Changes were made to the questionnaire items based on the results from the interviews. Secondly, an expert was invited to check and improve the wording of the questionnaire, word clarity, and relevance. As a result, a questionnaire of 10 items was finalized for further quantitative investigation.

Quantitative research methods such as surveys are the most widespread means of data collection in the hospitality and tourism industry [62]. Due to the availability of collecting large-scale data, a questionnaire survey was recommended by researchers. Therefore, we designed an intercultural questionnaire for this survey via an online website for both Chinese and overseas participants. The finalized questionnaire was administered to glean information from travelers of China and overseas. The questionnaire of this study was divided into three parts. The first part was related to the travel experiences of the respondents at travel destinations within the country, abroad, and within the state/province/city. The second part was related to the respondents' travel companions, such as family members, friends, and tour groups. The third part of the questionnaire was related to the transportation choices, for instance, private car, train, or plane. A linear 5-point rating scale was used, from 5 as very important, 4 as somewhat important, 3 as neutral, 2 as somewhat unimportant, and 1 as very unimportant. The respondents were asked to rate their responses from very important to very unimportant according to their judgment. Moreover, to consider the demographic factors that may play a role in this study, we also asked the participants to provide information on their gender, age, profession, location, and so forth. The questionnaire is provided as a Supplementary Material.

\subsection{Data Collection}

The survey was conducted from March 2020 to May 2020, after the travel ban when Wuhan was closed. An invitation link to the survey was posted on Sojump, an online platform. It is a reputable online data collection service provider in China, with an extensive database of 2.6 million users with diverse demographic and geographical backgrounds. The questionnaire was available in both Chinese and English languages for people with different language backgrounds. There was no difference in the questionnaires of both languages. Participants who volunteered to complete the survey were included in the sample. As a result, a total of 962 responses were collected. Out of these responses, 813 respondents were from mainland China, and the rest of the data were from overseas. All the respondents from mainland China were living in the country when the data were collected. However, the overseas respondents were living in their own countries with different cultural contexts from China. In addition, 27 overseas Chinese participants who had been living abroad for many years were also included in the survey.

Out of 962 responses, 20 responses were removed mainly due to the invalid answers. Finally, 942 responses remained and were used for data analysis. The ages of all the respondents ranged from under 20 to over 61. The respondents aged 20 to 30 were 
categorized into the young group; those who were 51 to 60 and over 60 were defined as the old group, while the rest were mid-ages. The professions of the respondents were diverse in this study, which could be a result of the universality of sampling.

Out of 942 respondents, 74 were from Beijing, 18 from shanghai, 11 from Tianjin, 112 from Hubei Province, 11 from Guangdong Province, 9 from Anhui Province, 116 from Hebei Province, 44 from Henan Province, 30 from Heilongjiang Province, 14 from Hainan Province, 43 from Neimenggu Province, 303 from Shanxi Province, 58 from Shandong province, 23 from Sichuan Province, 7 from Zhejiang Province, 4 from Yunnan Province, 7 from Shanxi province, 16 from Liaoning Province, 12 from Jiangxi Province, 4 from Jiangsu Province, 4 from Jilin Province, and 4 respondents were from Guangxi Province. For the foreign participants, 27 respondents were Chinese overseas, 16 from Spain, 22 from Greece, 6 from the USA, 8 from Pakistan, 6 from Portugal, 9 from British, 9 from India, 6 from Indonesia, 9 from Malaysia, 4 from Turkey, 4 from Slovenia, 2 from Egypt, 2 from Oman, 2 from Germany, 2 from Canada, 2 from Korea, 3 from Singapore, 3 from the UK, 1 from South Korea, 1 from Switzerland, 1 from Belgium, 1 from Italy, 1 from Netherland, 1 from Zanzibar, and 1 from Israel.

\section{Results}

\subsection{Descriptive Statistics of the Main Constructs}

Data for this study underwent descriptive statistics and multivariate statistics, including T-Tests and ANOVA. All the tests were conducted on IBM SPSS Statistics Program. The items, along with their mean scores, are presented in Table 1. As shown in Table 1, consumers indicated weak intentions of visiting a foreign destination with a mean of 1.85. Moreover, more preferred to travel inside the states with a mean of 3.09. Travel companions (questions 4-6) more often included family members with a mean of 3.03. For traveling transportation (questions 7-10), they seldom chose a cruise ship with a mean of 1.83. People would like to stay away from big groups and therefore did not take cruise ships, to avoid closed rooms with crowds of people. In general, Chinese consumers remained attentive to guidelines from the very early period of the pandemic outbreak.

Table 1. Items extracted from the questionnaire.

\begin{tabular}{ll}
\hline Items & Means \\
\hline 1. How likely will you travel outside your city or town or village, but inside your state, & 3.09 \\
in the next year? & 2.94 \\
2. How likely will you travel outside your state for domestic travel in the next year? & 1.85 \\
3. How likely will you travel to another country outside your country in the next year? & 2.04 \\
4. If you travel, how likely will you travel in an organized group tour next year? & 2.88 \\
5. If you travel, how likely will you travel with a small group of friends in the next year? & 2.03 \\
6. If you travel, how likely will you travel only with family or yourself in the next year? & 3.03 \\
7. If you travel, how likely will it be that you will travel mostly by car in the next year? & 2.42 \\
8. If you travel, how likely will you travel mostly by bus or train next year? & 2.72 \\
9. If you travel, how likely will it be that you will travel mostly by plane in the next year? & 2.68 \\
10. If you travel, how likely will it be that you will travel mostly by cruise ship in the & 1.83 \\
\hline & \\
\hline
\end{tabular}

\subsection{Multivariable Analysis/Hypotheses Testing}

As shown in Figure 1, both the age and country modulated the total score and became two variables. Within the variable of age, there were three conditions: Young, mid-age, and old. Further, within the variable of country, there was the mainland of China and other countries. For the total score, we conducted a multivariable analysis with age (young, mid-age, and old) and country (mainland and overseas respondents) as between-subject factors. The analysis showed that both age and country were significant for total score [F $(1.343)=7.832, p<0.01$, partial $\eta^{2}=0.022$ and $\mathrm{F}(2.343)=4.648, p<0.01$, partial $\eta^{2}=0.026$ for country and age conditions, respectively], revealing that the total score was larger for overseas respondents (29.7) than for the mainland (27.3), and that young people showed a 
lower total score (27.2) than mid-age people $(29.8, p<0.01)$, whereas there was no difference between mid-age and older people $(28.3, p=0.19)$. The two-way interaction of age * country was marginally significant $\left[\mathrm{F}(2.343)=2.649, p=0.07\right.$, partial $\left.\eta^{2}=0.015\right]$, showing that the modulation of age on total score was evident for mainland $(p<0.001)$ but not for overseas respondents $(p=0.887)$, and that the effect of country was significant for young people $(p<0.01)$ but not for the other two age groups $(p>0.1)$.

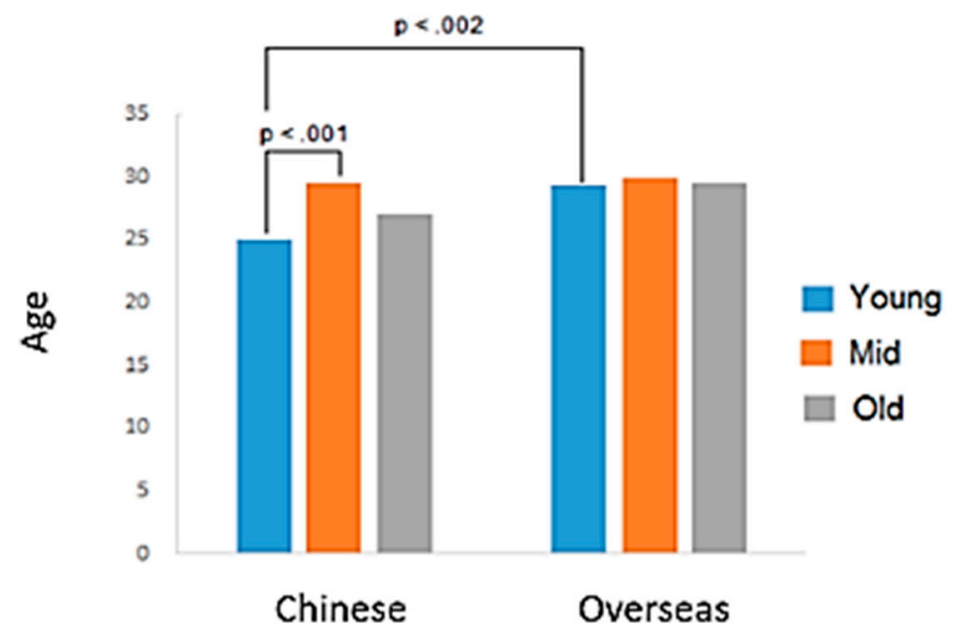

Figure 1. The total score for Chinese and overseas (other countries).

Both age and country modulated the score for each tour condition. For the score of each tour condition, we conducted a similar analysis to the above analysis for the total score. The results showed that the main effects of country were significant $(p<0.05)$ for each condition except friends' tours $(p=0.269)$ and plane tours $(p=0.095)$. The score was higher for mainland than for the overseas respondents for group tours (2.1 and 1.7 for mainland and overseas respondents, respectively; $p<0.01)$, train tours ( 2.9 and 2.5 for mainland and overseas respondents, respectively; $p<0.05)$, and ship tours (1.9 and 1.6 for mainland and overseas respondents, respectively; $p<0.05$ ), whereas for other tour conditions, the score was lower for mainland than for overseas respondents $(p<0.01)$. Additionally, the main effects of age were significant for local $\left[\mathrm{F}(2.343)=4.239, p<0.02\right.$, partial $\left.\eta^{2}=0.024\right]$, abroad $\left[\mathrm{F}(2.343)=5.099, p<0.01\right.$, partial $\left.\eta^{2}=0.029\right]$, private $\operatorname{car}[\mathrm{F}(2.343)=3.593, p<0.05$, partial $\left.\eta^{2}=0.021\right]$, and plane tour [F $(2.343)=5.654, p<0.01$, partial $\left.\eta^{2}=0.032\right]$ conditions but not for other tour conditions $(p>0.1)$, indicating that young people exhibited a lower score than mid-age and older people $(p<0.01)$ but with no difference between the latter two conditions $(p>0.1)$. Interestingly, we also found significant two-way interactions $(p<0.05)$ for abroad $\left[\mathrm{F}(2.343)=5.945, p<0.01\right.$, partial $\left.\eta^{2}=0.034\right]$, group $[\mathrm{F}(2.343)=3.919, p<0.05$, partial $\left.\eta^{2}=0.022\right]$, friends $\left[\mathrm{F}(2.343)=3.957, p<0.05\right.$, partial $\left.\eta^{2}=0.023\right]$, and family tour $\left[\mathrm{F}(2.343)=3.471, p<0.05\right.$, partial $\left.\eta^{2}=0.020\right]$ conditions but not for other tour conditions $(p>0.1)$. Further pairwise comparisons were conducted for each tour condition with a significant two-way interaction.

For abroad tour conditions, the score was higher for overseas respondents than for mainland for each age condition $(p<0.001)$. In contrast, for the mainland group, the score was higher for mid-age $(2.7)$ than for young $(1.9, p<0.001)$ and older people $(1.7, p<0.001)$ but did not differ between the latter two groups $(p=1.0)$, and for overseas respondents, the score was not modulated by age $(p=0.609)$. For the group tour condition, only older people showed any effect of country $(p<0.01)$, showing a higher score for the mainland (2.4) than the overseas respondents (1.5) condition. Neither young nor mid-age people showed significant country effects $(p>0.05)$. For the mainland group, the score was higher for the older group (2.4) than for the young group $(1.8, p<0.05)$ but did not differ between young and mid-age groups $(p=0.189)$. Therefore, for overseas respondents, the score was 
not modulated by age $(p=0.401)$. For the friends tour condition, both young and midage people showed a significantly higher score for mainland than overseas respondents $(p<0.01)$, but this effect was not evident for older people $(p=0.123)$. Therefore, the effect of age was not significant, regardless of the mainland $(p=0.071)$ or overseas respondents ( $p=0.184$ ) condition. For the family tour conditions, both young and mid-age people showed a significantly higher score for overseas respondents than the mainland condition $(p<0.01)$, but this effect was not evident for older people $(p=0.499)$. Thus, we did not find any significant age modulation, regardless of the mainland or overseas condition $(p<0.05)$.

\section{Discussions and Implications}

In order to support the tourism industry to recover from the impact of COVID-19, this intercultural survey was carried out to explore how different cultures impact the cognition and consumer behavior of tourists during the COVID-19 crisis. The results showed that cognition and consumer behavior differentiate culturally and significantly with the age of people when choosing traveling modes, transportation, and companions, especially for young people in China. In general, the results were quite different from overseas, and this difference is also shown in each of the extracted items from the questionnaire, partly indicating why COVID-19 control is likely to face significant differences between countries.

The traveling destination choice of young people was both culturally and significantly different. In their study, ref. [51] analyzed the impact of SARS on consumer behavior in Chinese tourists. They probed the sensitivity of consumers towards crises when making leisure travel decisions. The results indicated that SARS greatly affected people's life, work, and traveling during the outbreak of SARS, while the impact of SARS on people's s inclination to travel, their preference of leisure trips, and concern about public hygiene was different. The present research goes further and suggests that there are cultural differences associated with age differences. From Figure 1 of the three destination choices of the first three items, it can be assumed that young people have considerable variation from overseas respondents when choosing to travel, both going abroad and traveling within their own country or state. This potential cognition and culture of traveling may make isolation from COVID-19 difficult. Chinese young people were more likely to choose friends as companions when traveling. However, overseas young people were more likely to choose family as their companion. Regarding transportation, overseas young people were more likely to drive their car while Chinese young people chose "other." The results indicated that Chinese young people might not have owned a car or prefer to save money.

In their study, ref. [51] focused on people's lifestyles and travel activities during the crisis period. They showed how tourist activities virtually stopped during SARS, especially in the affected areas from the virus. The results showed that China's tourism industry experienced a dramatic decline. It indicates that tourists are susceptible to crises, which thus shows that the tourism industry has the characteristics of sensitivity and fluctuation. The current research provides additional insight suggesting that cognition may be rooted in culture. COVID-19 has affected the inclination and preferences of tourists, especially about the types of tours and travel patterns. People tend to be more interested in outdoor activities and eco-tourism, and city residents prefer to travel to the suburbs and countryside. The decrease in travel and tourism was caused by internal motivation, external compulsory measures, and travel bans. Tourist behavior, which follows the law of general human behavior, is closely related to the environment and individuality. In the long term, tourist destinations and enterprises should emphasize factors that have a long-term effect on people's behavior within marketing activities. They should also adopt crisis intervention measures for short-term changes. Ref. [47] proposed the existing cognitive biases are behind the rejection of government safety advisories during COVID-19. Although the paper was online, we were unable to access the research method and data.

The other difference between Chinese and overseas respondents is that Chinese respondents of any age chose to stay at home. However, the overseas respondents were more likely to travel abroad and places within their own country and state/province. 
There is also a big difference between overseas and Chinese respondents in selecting their destination choice abroad. Overseas respondents appear to exhibit a habit of traveling here and there.

In summary, the present study adds to the existing literature by conducting an empirical study on the impact of COVID-19 on consumer behavior in the tourism industry by conducting an intercultural survey. Theoretically, it provides a brief background on natural disasters and COVID-19 and examines its impact on China's tourism industry and many other countries. Furthermore, the study highlighted significant cross-cultural differences in tourists' choice of travel modes, transportation, and companions among different age groups. One of the other theoretical contributions of this paper is that it provides cultural insights into the varied tourism preference for people in China and other countries. Even though the government authorities, destination marketing and management organizations, and tourism providers are currently making every effort to reduce the harmful effects of COVID-19, they may not affect the individualistic characteristics of tourists. Therefore, tourism practitioners need to be aware of individual cultural differences, behavior, and choices. Thus, this study helps tourism providers and decision-makers of China and other countries to understand the changes in tourists' behaviors and help them develop proper strategies to revive the tourism industry during COVID-19 and post-COVID-19 periods.

\section{Limitations and Future Research}

This study also has the following limitations. First, Beijing was a COVID-19-infected city and had preventive access to survey respondents during the crisis period; therefore, the change of attitude could not be investigated well. Second, as the survey was conducted immediately after the ban was lifted by the World Health Organization (WHO), the percentage of respondents from the other parts of China outside of Beijing and foreign countries was small. Thus, future studies should collect the data from other Asian and European countries and test the study's objectives. Third, the data for this study were collected after the first weekend of lifting the ban; therefore, there may be a possibility that the sample population was less likely to be representative of the group. Finally, since this study was conducted during COVID-19, it may not provide a complete picture of the changes in consumer behaviors after the pandemic. Thus, future studies can also focus on changes that will remain the same in consumer behaviors and the changes that will taper off once the pandemic ends.

Supplementary Materials: The following are available online at https:/ /www.mdpi.com/article/10

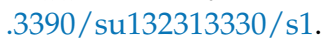

Author Contributions: X.C., Y.D. (Yachao Duan), L.A., Y.D. (Yahui Duan), K.R. contributed to the conceptualization, formal analysis, investigation, methodology, writing of the original draft, and writing. All authors have read and agreed to the published version of the manuscript.

Funding: This research received no external funding.

Institutional Review Board Statement: The study was conducted according to the guidelines of the Declaration of Helsinki, and approved by the Ethics Committee of Beijing Language and Culture University (2021-13-2020-11-12).

Informed Consent Statement: Informed consent was obtained from all subjects involved in the study.

Data Availability Statement: The data are not publicly available due to ethical reasons.

Conflicts of Interest: The authors declare no conflict of interest.

\section{References}

1. Gössling, S.; Scott, D.; Hall, C.M. Pandemics, tourism and global change: A rapid assessment of COVID-19. J. Sustain. Tour. 2021, 29, 1-20. [CrossRef]

2. Ali, F.; Dogan, S.; Amin, M.; Hussain, K.; Ryu, K. Brand anthropomorphism, love and defense: Does attitude towards social distancing matter? Serv. Ind. J. 2021, 41, 58-83. [CrossRef] 
3. UNWTO World Tourism Barometer. UNWTO World Tourism Barometer (English Version). Available online: https://doi.org/10 .18111/wtobarometereng (accessed on 12 July 2021).

4. Said, H.; Ali, L.; Ali, F.; Chen, X. COVID-19 and unpaid leave: Impacts of psychological contract breach on organizational distrust and turnover intention: Mediating role of emotional exhaustion. Tour. Manag. Perspect. 2021, 39, 100854.

5. UNWTO. 100\% of Global Destinations Now Have Covid-19 Travel Restrictions. Available online: https://www.unwto.org/ news / covid-19-travel-restrictions (accessed on 26 August 2020).

6. Specia, M. What You Need to Know about Trump's European Travel Ban. The New York Times. Available online: https: //www.nytimes.com/2020/03/12/world/europe/trump-travel-ban-coronavirus.html (accessed on 24 August 2020).

7. BBC. Coronavirus: Europe Plans Full Border Closure in Virus Battle. Available online: https://www.bbc.com/news/worldeurope-51918596 (accessed on 17 March 2020).

8. Radic, A.; Koo, B.; Gil-Cordero, E.; Cabrera-Sánchez, J.P.; Han, H. Intention to take COVID-19 vaccine as a precondition for international travel: Application of extended norm-activation model. Int. J. Environ. Res. Public Health 2021, 18, 3104. [CrossRef]

9. Blackbox. Most Countries' COVID-19 Responses Rated Poorly by Own Citizens in First-of-Its-Kind Global Survey. Available online: https:/ /blackbox.com.sg/everyone/2020/05/06/most-countries-covid-19-responses-rated-poorly-by-own-citizensin-first-of-its-kind-global-survey (accessed on 6 March 2021).

10. Reuters. Macau's Leader Warns of Over Reliance on Gaming Industry in Wake of COVID-19. 2020. Available online: https: / / www.reuters.com/article/us-macaupolitics/macaus-leader-warns-of-over-reliance-on-gamingindustry-in-wake-ofcovid-19-idUSKBN2220XR (accessed on 18 June 2020).

11. McCartney, G. The impact of the coronavirus outbreak on Macao. From tourism lockdown to tourism recovery. Curr. Issues Tour. 2021, 24, 2683-2692. [CrossRef]

12. Van De Vijver, F.J.R.; Leung, K. Methodological issues in psychological research on culture. J. Cross-Cult. Psychol. 2000, 31, 33-51. [CrossRef]

13. Wang, D.F.; Cui, H.; Zhou, F. Measuring the personality of Chinese: QZPS versus NEOPI-R. Asian J. Soc. Psychol. 2005, 8, 97-122. [CrossRef]

14. Hammer, M.R. Additional cross-cultural validity testing of the intercultural development inventory. Int. J. Intercult. Relat. 2011, 35, 474-487. [CrossRef]

15. Bontempo, R.N.; Bottom, W.P.; Weber, E.U. Cross-cultural differences in risk perception: A Model-Based Approach. Risk Anal. 1997, 17, 479-488. [CrossRef]

16. Reisinger, Y.; Mavondo, F. Cultural consequences on traveler risk perception and safety. Tour. Anal. 2006, 11, 265-284. [CrossRef]

17. Abulibdeh, A.; Zaidan, E. Empirical analysis of the cross-cultural information searching and travel behavior of business travelers: A case study of MICE travelers to Qatar in the Middle East. Appl. Geogr. 2017, 85, 152-162. [CrossRef]

18. Wen, J.; Huang, S.; Ying, T. Relationships between Chinese cultural values and tourist motivations: A study of Chinese tourists visiting Israel. J. Destin. Mark. Manag. 2019, 14, 100367. [CrossRef]

19. Pizam, A.; Jeong, G.-H.; Reichel, A.; van Boemmel, H.; Lusson, J.M.; Steynberg, L.; State, O.; Volo, S.; Kroesbacher, C.; Kucerova, J.; et al. The relationship between risk-taking, sensation-seeking, and the tourist behavior of young adults: A cross-cultural study. J. Travel Res. 2004, 42, 251-260. [CrossRef]

20. Roehl, W.; Fesenmaier, D. Risk Perceptions and Pleasure Travel: An Exploratory Analysis. J. Travel Res. 1992, 2, 17-26. [CrossRef]

21. Reisinger, Y.; Mavondo, F. Cultural differences in travel risk perception. J. Travel Tour. Mark. 2006, 20, 13-31. [CrossRef]

22. Cheron, E.; Ritchie, J. Leisure activities and perceived risk. J. Leis. Res. 1982, 14, 139-154. [CrossRef]

23. Dowling, G.R.; Staelin, R. A model of perceived risk and intended risk-handling activity. J. Consum. Res. 1994, 21, 119-135. [CrossRef]

24. Ropeik, D. Fear Factors in an Age of Terrorism. Available online: http://www.msnbc.com/news/643092.asp?cp1=1 (accessed on 3 March 2004).

25. Reisinger, Y.; Mavondo, F. Travel anxiety and intentions to travel internationally: Implications of travel risk perception. J. Travel Res. 2005, 43, 212-225. [CrossRef]

26. Sönmez, S.F.; Graefe, A.R. Influence of terrorism risk on foreign tourism decisions. Ann. Tour. Res. 1998, 25, 112-144. [CrossRef]

27. Weisaeth, L.; Knudsen, O.; Tonnessen, A. Technological disasters, crisis management and leadership stress. J. Hazard. Mater. 2002, 93, 33-45. [CrossRef]

28. Smith, K. Environmental Hazards: Assessing Risk and Reducing Disaster; Routledge: London, UK, 2013.

29. Becken, S.; Mahon, R.; Rennie, H.; Shakeela, A. The Tourism Disaster Vulnerability Framework: An application to tourism in small island destinations. Nat. Hazards 2014, 71, 955-972. [CrossRef]

30. Munich, R. Press Release: Natural Catastrophe Review: Series of Hurricanes Makes 2017 Year of Highest Insured Losses Ever. Available online: https:/ / www.munichre.com/en/media-relations/publications / press-releases/2018/2018-01-04-press-release / index.html (accessed on 4 January 2018).

31. Lepp, A.; Gibson, H. Tourist roles, perceived risk and international tourism. Ann. Tour. Res. 2003, 30, 606-624. [CrossRef]

32. Fuchs, G.; Pizam, A. The Importance of Safety and Security for Tourism Destinations. In Destination Marketing and Management; Wang, Y., Pizam, A., Eds.; CABI: Oxfordshire, UK, 2011; pp. 300-313.

33. Wolff, K.; Larsen, S.; Øgaard, T. How to define and measure risk perceptions. Ann. Tour. Res. 2019, 79, 102759. [CrossRef] 
34. Hall, C.M. Tourism, disease and global environmental change. In Tourism and Global Environmental Change; Gossling, S., Hall, M., Eds.; Routledge: New York, NY, USA, 2006; pp. 173-193.

35. Richter, L.K. International tourism and its global public health consequences. J. Travel Res. 2003, 41, 340-347. [CrossRef]

36. Godovykh, M.; Pizam, A.; Bahja, B. Antecedents and outcomes of health risk perceptions in tourism, following the COVID-19 pandemic. Tour. Rev. 2021, 76, 737-748. [CrossRef]

37. Jonas, A.; Mansfeld, Y.; Paz, S.; Potasman, I. Determinants of health risk perception among low-risk-taking tourists traveling to developing countries. J. Travel Res. 2011, 50, 87-99. [CrossRef]

38. Chen, J.S.; Hsu, C.H. Measurement of Korean tourists' perceived images of overseas destinations. J. Travel Res. 2000, 38, 411-416. [CrossRef]

39. Oppermann, M. Convention destination images: Analysis of association meeting planners' perceptions. Tour. Manag. 1996, 17, 175-182. [CrossRef]

40. Leisen, B. Image segmentation: The case of a tourism destination. J. Serv. Mark. 2001, 15, 49-66. [CrossRef]

41. San Martín, H.; del Bosque, I.A. Exploring the cognitive-affective nature of destination image and the role of psychological factors in its formation. Tour. Manag. 2008, 29, 263-277. [CrossRef]

42. Baloglu, S. A path analytic model of visitation intention involving information sources, socio-psychological motivations, and destination image. J. Travel Tour. Mark. 1999, 8, 81-91. [CrossRef]

43. Pike, S.; Ryan, C. Destination positioning analysis through a comparison of cognitive, affective, and conative perceptions. J. Travel Res. 2004, 42, 333-342. [CrossRef]

44. Kim, H.; Richardson, S.L. Motion picture impacts on destination images. Ann. Tour. Res. 2003, 30, 216-237. [CrossRef]

45. Walmsley, D.J.; Jenkins, J.M. Appraisive images of tourist areas: Application of personal construct. Aust. Geogr. 1993, $24,1-13$. [CrossRef]

46. Beerli, A.; Martı'n, J.D. Tourists' characteristic and the perceived image of tourist destinations: A quantitative analysis-Acase study of Lanzarote, Spain. Tour. Manag. 2004, 25, 623-636. [CrossRef]

47. Chen, P.-J.; Kerstetter, D.L. International students' image ofrural Pennsylvania as a travel destination. J. Travel Res. 1999, 37, 256-266. [CrossRef]

48. Hui, T.K.; Wan, T.W.D. Singapore's image as a tourist destination. Int. J. Tour. Res. 2003, 5, 305-313. [CrossRef]

49. Roy, D.; Sinha, K. Cognitive biases operating behind the rejection of government safety advisories during COVID19 pandemic. Asian J. Psychiatry 2020, 51, 102048. [CrossRef] [PubMed]

50. Luo, L.; Zeng, X.; Liao, X.; Yang, Y. Disease cognition, coping style and exercise behavior among the public during novel coronavirus epidemic: An online survey. Chin. J. Public Health 2020, 36, 156-159.

51. Wang, C.; Horby, P.W.; Hayden, F.G.; Gao, G.F. A novel coronavirus outbreak of global health concern. Lancet 2020, 395, 470-473. [CrossRef]

52. Zhang, W.; Gu, H.; Kavanaugh, R.R. The Impacts of SARS on the Consumer Behaviour of Chinese Domestic Tourists. Curr. Issues Tour. 2005, 8, 22-38.

53. Liu, F. Analysis and Solutions of the Impact of SARS on China's Tourism Industry, Other Information? Dangjian Reading Matter Publishing House: Beijing, China, 2003.

54. Ali, L.; Ali, F. Perceived risks related to unconventional restaurants: A perspective from edible insects and live seafood restaurants Food Control. 2022, 131, 108471. Available online: https://www.sciencedirect.com/science/article/abs/pii/S0956713521006095 (accessed on 15 August 2021). [CrossRef]

55. Cai, J. Pay Attention to the Influences of SARS on the Psychological Changes of Tourists. China Tourism News. 2003. Available online: http:/ / news.ctnews.com.cn/article/3145468 (accessed on 26 February 2020).

56. OECD. OECD Economic Outlook, Volume 2020 Issue 2: Preliminary Version; OECD Publishing: Paris, France, 2020; Available online: https:/ / www.oecd-ilibrary.org/economics/oecd-economic-outlook/volume-2020/issue-2_39a88ab1-en (accessed on 1 December 2020).

57. Tang, R. Five Changes Brought by COVID 19 to China in the Future. Guang Ming Daily. Available online: http:/ / theory.gmw.cn/ 2020-03/17/content_33657787.htm (accessed on 20 March 2020).

58. Huang, C.; Wang, Y.; Li, X.; Ren, L.; Zhao, J.; Hu, Y.; Zhang, L.; Fan, G.; Xu, J.; Gu, X.; et al. Clinical features of patients infected with 2019 novel coronavirus in Wuhan, China. Lancet 2020, 395, 497-506. [CrossRef]

59. Song, F.; Shi, N.; Shan, F.; Zhang, Z.; Shen, J.; Lu, H.; Ling, Y.; Jiang, Y.; Shi, Y. Emerging 2019 Novel Coronavirus (2019-nCoV) Pneumonia. Radiology 2020, 295, 210-217. [CrossRef]

60. Lu, R.; Zhao, X.; Li, J.; Niu, P.; Yang, B.; Wu, H.; Wang, W.; Song, H.; Huang, B.; Zhu, N.; et al. Genomiccharacterisation and epidemiology of 2019 novel coronavirus: Implications for virus origins and receptor binding. Lancet 2020, 395, 565-574. [CrossRef]

61. Zhu, N.; Zhang, D.; Wang, W.; Li, X.; Yang, B.; Song, J.; Zhao, X.; Huang, B.; Shi, W.; Lu, R.; et al. A novel coronavirus from patients with pneumonia in China, 2019. N. Engl. J. Med. 2020, 382, 727-733. [CrossRef] [PubMed]

62. Ali, F.; Koseoglu, M.A.; Okumus, F.; Putra, E.D.; Yildiz, M.; Dogan, I.C. Is lodging research suffering from methods bias? An assessment of published research during 1990-2016. J. Hosp. Tour. Technol. 2021, 12, 423-438. [CrossRef] 